\title{
KERRY WOOD'S "NATURE GUIDE FOR FARVERS"
}

Those of our readers who have had the privilege of reading "Three Mile Bent," "Animals of the Rockies" and "Nature Guide for Farmers" cannot help but feel that the wild. Iife of the West, particularly the wild animal life, have in Mr. Kerry Wood their most valued friend and protector. His books are most interesting and his suggestions for conservation are based on practical knowledge and keen personal observation. I feel in particular that each of our members should obtain and thoroughly digest the contents of his "A Nature Guide for Farmers" (H.R. Iawson Publishing Oo., Saskatoon). In this most instructive book he discusses from the point of view of the thoughtful farmer the friends and "Varmints" among our birds and mammals. I know of no nature book that I have read with such interest and enthusiasm. Editor.

\section{AUDUBON NEWS IETTER}

Mr. W. A. Brownlee, of Regina, has given us a copy of the first issue of the Audubon News Letter, which was sent out in December. These letters are dedicated to the conservation of oun Natural Resources and make very interesting and instructive reading. Among other items this issue deals with the present status of the Whooping Orane, with Hawk and Owl protection and with an account of Audubon Wildiffe Tours. You can get your name on the mailing list by writing to the National Audubon Society, 1000 Fifth Ave., New York 28.

A Post-deadine story.

\section{A ONE-WINGED DUCK $\quad$ By R.D. Caskey, Armley}

A few years ago, just before freeze-up, I noticed a mallard drake on my pond. All the other ducks had gone south so I concluded he was a cripple and decided to shoot him before winter set in. Next day there were two drakes there and both flew up as I approached. One got no mor $\theta$ than six feet up and. then coasted down. The other circled and lit beside him. As I came nearer, the sound one flew away and didn't retura. I headed the cripple up a runway and finally got him.

I thought he had lost one wing and it wasn t until I had him dressed. that I noticed he nerer had a second wing. The skin showed no scar and was perfectly smooth over the area where the wing should have joined the body. I cannot understand how he reached maturity, handicapped as he was, with so many natural enemies around. But he was in prime condition.

It is very unfortunate that we have not been able to publish a great deal of the material that has been so generously contributed. We hope the writers will understand that the reason is lack of space and selections have to be made. Of those stories published practically all have been drastically cut. We are sorry but it could not be helped.

On the outside of the envelope containing the BIUE JAY you will find the date to which your subscription has jeen paid. Should an error appear to be present, do not hesitate to tell us about it. 

B34048 